\title{
Influence of cadmium on early growth of fluted pumpkin (Telfairia occidentalis Hook F.) and nutrient uptake in an ultisol
}

\author{
Ehi R obert Orhue ${ }^{1 *}$ and A khere $M$ athew Ekhomun ${ }^{2}$ \\ 'Department of Soil Science, Faculty of Agriculture, University of Benin, Benin City, NIGERIA \\ ${ }^{2}$ Department of Crop Science, Faculty of Agriculture, University of Benin, Benin City, NIGERIA \\ *Corresponding author. E-mail: orhuerob@yahoo.com
}

\begin{abstract}
The greenhouse and field trials were conducted at the University of Benin, Benin City, Nigeria to determine the influence of $\mathrm{Cd}$ on the growth, dry matter yield and nutrient uptake by fluted pumpkin (Telfairia occidentalis). Four levels of $\mathrm{Cd}\left(\mathrm{NO}_{3}\right)_{2}$ treatments namely $0,50,100,200 \mathrm{mg}$ per $5 \mathrm{~kg}$ soil equivalent to $0,20,40,80 \mathrm{kgha}^{-1}$ were used in the greenhouse and field trials respectively. The completely randomized and randomized complete block experimental designs were used in the greenhouse and field trials respectively. Results indicated that increased application of $\mathrm{Cd}$ decreased the height, number of leaves, leaf area, stem girth and dry matter yield of the plant. The nutrients content and uptake also decreased with the increase in the supply of the $\mathrm{Cd}$. Higher Cd concentrations and uptake were recorded in the root of the treated plants when compared to the control treatments. The nutrients and oxides components of the soil decreased at various levels of the $\mathrm{Cd}$ application. These decrease in soil nutrient components were however not consistent. However, the Cd content of the soil increased with increased Cd treatments.
\end{abstract}

Keywords: Ultisol, Uptake, Yield, Metal excluder, Pumpkin

\section{INTRODUCTION}

Although cadmium is a naturally occurring element, it is rarely found a pure metal in nature. It is generally associated with oxygen, chloride, sulphates and sulphides and is often a by -product of extraction of $\mathrm{Pb}$, $\mathrm{Zn}$ and $\mathrm{Cu}$ from their respective ores (ATSDR, 1999). The anthropogenic sources of $\mathrm{Cd}$ in the soil nowadays include the use of commercially available fertilizers and disposal of sewage sludge as soil amendments (Singh 2001, McBride, 2003). Others include pesticides, irrigation water, biomass burning, coal and oil combustion, mining activities, foundries and industrial refineries (Adriano, 1986 ). The cadmium $(\mathrm{Cd})$ is one of those heavy metals that is toxic to plants and animals at low concentration. Cadmium can accumulate in high concentration in soils and it is recalcitrant in the soil profile particularly in the surface horizons (John, et al., 1972, Khan and Frankland, 1983). The $\mathrm{Cd}$ is not very mobile and the immobilization can increase its concentration in the soil and ultimately lead to increase in toxicity of the contaminated soil.

The higher soil Cd concentration can result in higher levels of its uptake by plants (John et al., 1972) and resultant bioaccumulation in the plant tissue. Investigation by Subramani et al. (1997) revealed that the germination and seedling growth of black grain (Vigna mungo (L) Hepper) showed a gradual decline with the increase in the concentration of $\mathrm{Cd}$ treatments. Kramer and Konig (1983) recorded high Cd content in the grain and vegetative parts of wheat and oat while Brown et al. (1983) reported high uptake of Cd by Cynodon dactylon. Nasu et al. (1984) also reported that Cd ion which is plant part specific in Lemna pancicostato suppressed its fronds multiplication and that the degree of the $\mathrm{Cd}$ effect depends on its concentration absorbed. B eta vulgaris $L$, Rephenus sativus and Lycopersicum esulentus did not extract appreciable $\mathrm{Cd}$ from soil at indigenous levels but following the initiation of elevated levels, $\mathrm{Cd}$ was detected in all the harvested crop tissues. The mineral nutrition acquisition by common bean plant as recorded by Azmat et al. (2005) also decreased with increase in $\mathrm{Cd}$ ion concentration. Pinero et al. (2002) reported that at higher concentration of $\mathrm{Cd}$ the biomass production, chlorophyll concentration of common bean (P haseolus vulgaris), Alfalfa (M edicago sativa), Avena (Avena sativa) and Rye grass (Lotium multiflorum) decreased to levels below the control.

However, Re et al. (1983) showed that Cd accumulation by 'different plant parts could reach a saturation level without the appearance of phytotoxic symptoms. Therefore, Cd pollution of the soil could remain undetected even when the plants were grown in the presence of consistently high level of Cd. Crops which exhibit this character tends to accumulate $\mathrm{Cd}$ where it is detoxified by binding to phytochelatins, a family of thiol- 
(SH) rich peptides (Stiffens, 1990 and Rauser, 1990). The uptake of this cadmium by crops results in the bioaccumulation of the metal in the plant tissue. One of the ways by which this $\mathrm{Cd}$ is consumed is via the food chain and if the consumption through crops sources is not carefully regulated it may lead to accumulation in man with high attendant health hazards. The consumption of $\mathrm{Cd}$ has been reported to cause gastro intestinal, hematological, musculoskeletal, renal, neurological and reproductive adverse health effects (ATSDR, 1999).

The plant pumpkin (Telfairia occidentalis) is a herbaceous annual creeping or climbing crop that grows to about $6 \mathrm{~m}$ in length. The soft round stems have large leaves that are trifoliate. The crop can produce up to 3-6 pods and the number of seeds per pod depends on the size of the pod. The seeds and leaves are widely consumed in tropical Africa and the plant is highly nutritive. This study was undertaken to determine the influence of $\mathrm{Cd}$ on some soil chemical properties, nutrient content and uptake and some growth parameters of T. occidentalis.

\section{MATERIALS AND METHODS}

The greenhouse and field trials were conducted at the experimental site of the Faculty of Agriculture, University of Benin, Benin City, Nigeria.

Greenhouse trial: In the greenhouse trial, soil samples were collected from surface $0-15 \mathrm{~cm}$ depth, bulked, mixed thoroughly, air dried and then sieved to remove debris. Thereafter, $5 \mathrm{~kg}$ of the composite soil was weighed and put in each of the plastic pots. Thirty-six pots were used with twelve pots per replicate and three pots per treatment. Four levels namely 0, 50, 100 and $200 \mathrm{mg}$ $\mathrm{Cd}\left(\mathrm{NO}_{3}\right)_{2}$ per $5 \mathrm{~kg}$ soil were used. The soils were polluted two weeks before transplanting one seedling per polythene pot to enable the $\mathrm{Cd}$ equilibrates with the soil. The experiment was organized in a completely randomized design with three replicates. Watering and weeding were carried out regularly. The trial was left for 40 days and thereafter the crops were harvested. The shoots were separated from the roots, dried in a ventilated oven at $70 \%$ for 48 hours to constant weight used in determining nutrient uptake. Prior to oven drying, data on height, number of leaves, stem girth and leaf area was taken. The plant height was determined by measuring from soil level to the tip of the topmost leaf. The heights of the entire plants in a treatment were used and mean computed. The number of leaves of all the fully opened leaves per pot was counted in a treatment and the mean taken. The stem girth was determined with a measuring tape. Also the entire plants in a treatment were used and the mean calculated. The leaf area of the entire opened leaves per plant were used. The leaf area was determined using the leaf area meter.

Field trial: The field experiment was sited where the soil for greenhouse trial was taken. The trial was carried out in a plot size of $10 \mathrm{~m} \times 12 \mathrm{~m}\left(120 \mathrm{~m}^{2}\right)$. The same $\mathrm{Cd}\left(\mathrm{NO}_{3}\right)_{2}$ rates of $0,50,100,200 \mathrm{mg}$ per $5 \mathrm{~kg}$ soil equivalent to 0,20 , $40,80 \mathrm{~kg} \mathrm{ha}^{-1}$ were used. Each treatment was represented by a bed size of $1.6 \mathrm{~m}$ x $1.6 \mathrm{~m}$ separated by $50 \mathrm{~cm}$ space while each replicate was separated by $1 \mathrm{~m}$ alley. The various levels of $\mathrm{Cd}\left(\mathrm{NO}_{3}\right)_{2}$ were uniformly applied, thoroughly mixed and then left for two weeks before transplanting the seedlings. The seedlings were sown at a spacing of $1 \mathrm{~m} \mathrm{x} 1 \mathrm{~m}$ with four seedlings per bed. Weeding and watering carried out regularly. The trial lasted for 40 days. The mode of data collection was similar to that of the greenhouse trial.

Soil analysis: Soils were analyzed at the beginning and at the end of the trials. Soil $\mathrm{pH}$ was determined by using $\mathrm{pH}$ meter while the soil particle size was done by hydrometer method of Bouyoucos (1951) as modified by Day (1965). The organic carbon was determined by chromic acid wet oxidation procedure of Walkey and Black (1934) as modified by Black (1965). The total N was determined by micro-kjeldal procedure as described by Jackson (1962) whereas the available $P$ was extracted by using Bray No $1 \mathrm{P}$ solution, and the $\mathrm{P}$ in the extract assayed calorimetrically by molybdenum blue colour method of Murphy and Riley (1962). The exchangeable bases were extracted using $1 \mathrm{~N}$ neutral ammonium acetate solution. The $\mathrm{Ca}$ and $\mathrm{Mg}$ content of the extract were determined volumetrically by EDTA titration procedure (Black, 1965). The $\mathrm{K}$ and Na were determined by flame photometry and Mg content obtained by difference. The heavy metals and oxides were determined by methods Soon and Abboud (1993). The data generated were analyzed by Genstat statistical version 6.1.0 234 (Payne, 2002).

Plant analysis: The plant materials were ground $(<1 \mathrm{~mm})$ and then digested with a mixture of $\mathrm{HNO}_{3}, \mathrm{H}_{2} \mathrm{SO}_{4}$ and $\mathrm{HClO}_{4}$ acids (IITA, 1979). The mineral ions ( $\mathrm{Na}, \mathrm{K}, \mathrm{Ca}$, $\mathrm{Mg}, \mathrm{Fe}, \mathrm{Mn}, \mathrm{Zn}$ and $\mathrm{Cd}$ ) were determined by the use of atomic absorption spectrophotometer (AAS UNICAM 969). For P content (AOAC, 1970) perchloric acid digestion (wet oxidation) method was used while the micro-kjeldal method of Jackson ( 1962 ) was used for N determination.

\section{RESULTS AND DISCUSSION}

Properties of the soil used: The properties of the soil used are shown in Tables 1and 2.The soil used is acidic and texturally sandy loan. The soil is low in fertility and have low Cd component that is below the (WHO, 1984) acceptable level of $0.3 \mathrm{mgkg}^{-1}$. In the greenhouse and field trials, the Organic carbon, $\mathrm{N}, \mathrm{P}, \mathrm{K}, \mathrm{Mg}, \mathrm{Ca}, \mathrm{Na}, \mathrm{Fe}, \mathrm{Mn}$, and $\mathrm{Zn}$ components of the soil declined after the trial. The decline of these nutrients was not consistent and this inconsistent decrease may be attributed to plant uptake at various levels of $\mathrm{Cd}$ treatment. The $\mathrm{Cd}$ content of the soil also increased with increase in $\mathrm{Cd}$ application. 
Table 1. Some physico-chemical properties of the soil used in the trial.

\begin{tabular}{|c|c|c|}
\hline Properties & $\begin{array}{c}\text { Greenhouse } \\
\text { value }\end{array}$ & $\begin{array}{l}\text { Field } \\
\text { value }\end{array}$ \\
\hline $\mathrm{pH}(1: 1)$ & 5.01 & 5.65 \\
\hline Organic carbon $(\%)$ & 4.10 & 4.30 \\
\hline Total N (\%) & 0.60 & 0.67 \\
\hline Av P $\left(\mathrm{mgkg}^{-1}\right)$ & 2.63 & 2.70 \\
\hline $\mathrm{Ca}$ cmolkg- & 1.60 & 1.63 \\
\hline $\mathrm{Mg} \mathrm{cmolkg}^{-}$ & 0.30 & 0.31 \\
\hline $\mathrm{K} \mathrm{cmolkg}^{-1}$ & 0.09 & 0.10 \\
\hline $\mathrm{Na}$ cmolkg- & 0.06 & 0.09 \\
\hline Free Fe Oxides $\%$ & 4.93 & 4.92 \\
\hline Free Al Oxides \% & 0.74 & 0.76 \\
\hline Amorphous Fe oxide \% & 0.07 & 0.06 \\
\hline Amorphous Al oxide \% & 0.03 & 0.03 \\
\hline $\mathrm{Cd} \mathrm{mgkg}^{-1}$ & 0.001 & 0.001 \\
\hline $\mathrm{Fe} \mathrm{mgkg}^{-1}$ & 0.03 & 0.04 \\
\hline $\mathrm{Mn} \mathrm{mgkg}^{-1}$ & 0.05 & 0.05 \\
\hline $\mathrm{Zn} \mathrm{mgkg}^{-1}$ & 0.24 & 0.27 \\
\hline Sand $\mathrm{gkg}^{1}$ & 865.31 & 864.32 \\
\hline Silt gkg ${ }^{1}$ & 12.39 & 14.37 \\
\hline Clay gkg ${ }^{1}$ & 122.30 & 121.31 \\
\hline Textural class & Sandy loam & Sandy loam \\
\hline
\end{tabular}

The increase in soil Cd component is attributed to increase in amount of $\mathrm{Cd}$ applied. The increase in concentration of $\mathrm{Cd}$ in the soil used correspond to the studies of Kachenko and Singh (2004) and Tam and Singh (2004) who reported similar high concentration of Cd in soil from within the smelter compound. The oxides also declined at the various levels of $\mathrm{Cd}$ treatments. The decrease in oxides also may be due to the oxide solubility at low soil pH. Schwertmann (1991) has earlier reported similar results of oxides solubility at low soil $\mathrm{pH}$. The oxides according to Schwertmann (1991) are very low at the $\mathrm{pH}$ range of soils and depend on the particle size, crystalinity and percent of $\mathrm{Al}$ substitution.

E ffect of cadmium on plant height, number of leaves, leaf area, stem girth and dry matter yield of $\mathrm{T}$. occidentalis: Table 3 indicated the effect of the $\mathrm{Cd}$ on the growth and dry matter yield of the pumpkin. The height, number of leaves, leaf area and stem girth decreased with increase in the concentration of $\mathrm{Cd}$ applied. The $\mathrm{Cd}$ rates influenced the growth parameters so much that the treated plants consistently gave low values compared to the control. The various treatments were however not significantly different from one another in the growth parameters. This retarded growth recorded especially in those treated with $\mathrm{Cd}$ is a commonly observed growth response in a wide range of plants cultivated in metal laden soils as reported by Foy et al. (1978). The Cd treatment also had an appreciable effect on the shoot and root dry weight of the plant (Table 3) with significant differences recorded among various $\mathrm{Cd}$

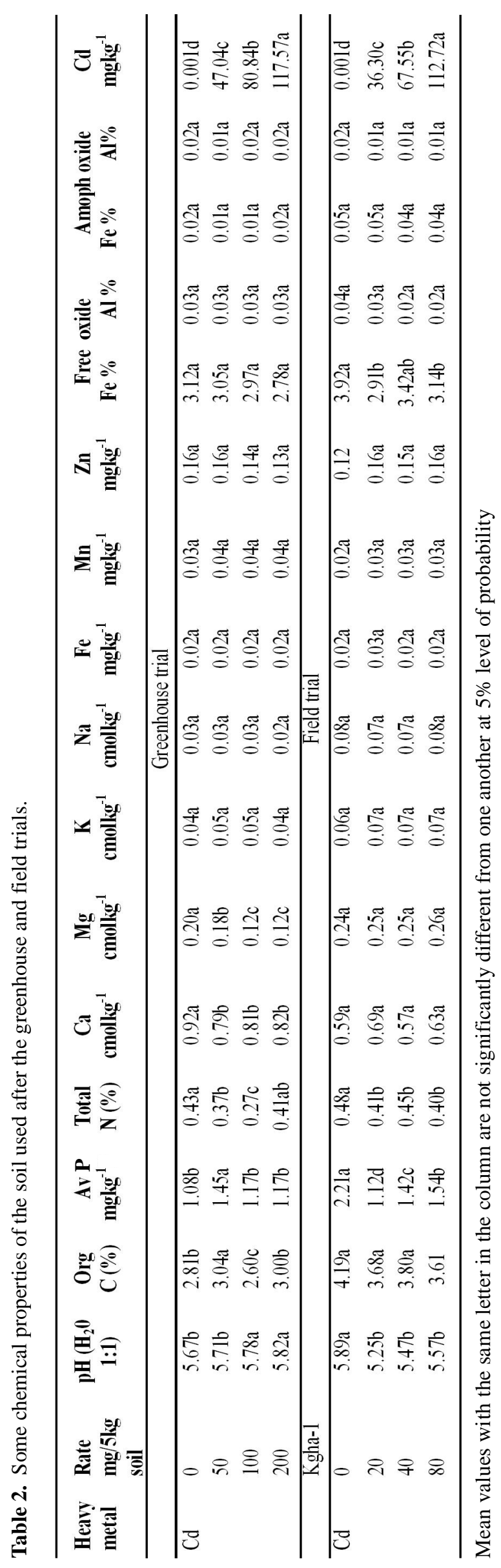


Table 3. Effect of cadmium on plant height, number of leaves, leaf area, stem girth and dry matter yield of T. occidentalis in greenhouse and field trials.

\begin{tabular}{|c|c|c|c|c|c|c|c|}
\hline $\begin{array}{l}\text { H eavy } \\
\text { M etal }\end{array}$ & $\begin{array}{l}\mathrm{mg} / 5 \mathrm{~kg} \\
\text { soil }\end{array}$ & $\begin{array}{l}\text { Plant height } \\
(\mathrm{cm})\end{array}$ & $\begin{array}{l}\text { Number of } \\
\text { leaves }\end{array}$ & $\begin{array}{c}\text { L eaf area } \\
\left(\mathrm{cm}^{2}\right)\end{array}$ & $\begin{array}{l}\text { Stem girth } \\
(\mathrm{cm})\end{array}$ & $\begin{array}{l}\text { Shoot dry } \\
\text { weight }(g)\end{array}$ & $\begin{array}{l}\text { Root dry } \\
\text { weight (g) }\end{array}$ \\
\hline & & \multicolumn{6}{|c|}{ Greenhouse trial } \\
\hline \multirow[t]{5}{*}{$\mathrm{Cd}$} & $\overline{0}$ & $63.17 \mathrm{a}$ & $23.67 \mathrm{a}$ & $26.63 a$ & $2.75 a$ & $4.83 a$ & $0.86 a$ \\
\hline & 50 & $59.37 \mathrm{a}$ & $23.33 \mathrm{a}$ & $24.20 \mathrm{a}$ & $2.20 \mathrm{a}$ & $3.55 \mathrm{ab}$ & $0.75 b$ \\
\hline & 100 & $46.33 \mathrm{a}$ & $21.37 \mathrm{a}$ & $23.80 \mathrm{a}$ & $2.00 \mathrm{a}$ & $3.29 \mathrm{ab}$ & $0.66 \mathrm{c}$ \\
\hline & 200 & $38.83 \mathrm{a}$ & $19.67 \mathrm{a}$ & $19.58 \mathrm{a}$ & $2.00 \mathrm{a}$ & $2.39 b$ & $0.58 \mathrm{~d}$ \\
\hline & $\mathrm{Kgha}^{-1}$ & \multicolumn{6}{|c|}{ Field trial } \\
\hline \multirow[t]{4}{*}{$\mathrm{Cd}$} & 0 & $101.24 \mathrm{a}$ & $36.11 \mathrm{a}$ & $38.78 \mathrm{a}$ & $3.16 \mathrm{a}$ & $8.27 \mathrm{a}$ & $1.56 \mathrm{a}$ \\
\hline & 20 & $80.00 \mathrm{a}$ & $33.78 \mathrm{a}$ & $38.22 \mathrm{a}$ & $2.76 \mathrm{a}$ & $5.84 b$ & $1.34 b$ \\
\hline & 40 & $76.22 \mathrm{a}$ & $32.67 \mathrm{a}$ & $35.33 a$ & $2.21 \mathrm{a}$ & $4.97 b$ & $0.94 \mathrm{c}$ \\
\hline & 80 & $68.55 \mathrm{a}$ & $31.33 \mathrm{a}$ & $28.44 \mathrm{a}$ & $1.90 \mathrm{a}$ & $3.58 \mathrm{c}$ & $0.92 \mathrm{c}$ \\
\hline
\end{tabular}

Mean values with the same letter in the column are not significantly different from one another at $5 \%$ level of probability

levels in greenhouse and field trials The dry weight also decline with increase in the concentration of Cd treatment. Orhue (2008) while citing Azmat and Haider (2007) reported that the depression in root growth in the $\mathrm{Cd}$ treated soils could be attributed to lack of oxygen because of the heavy metal application. Godzik (1993) reported that nutrients are generally absorbed against concentration gradients; consequently, respiratory energy is required for mineral uptake. In order for respiration to continue in the roots, oxygen must be available in root zone (Azmat and Haider, 2007). Roots, which become totally submerged in soil contaminated by heavy metals, will suffer from lack of oxygen, and this will lead to slow growth and inhibitory effect of toxic metal on root of plants (Jones et al., 1973).

Shoot miner al nutrients and uptake by T. occidentalis: Tables 4 and 5 depicted the shoot mineral concentration and uptake respectively. Again, the nutrients concentration and uptake consistently decrease with increase in $\mathrm{Cd}$ application in the greenhouse and field trials. The mineral nutrients concentration (Table 4) in the shoot recorded significant differences among the various $\mathrm{Cd}$ treatments. The uptake (Table 5) of the minerals by the shoot recorded the control to be consistently significantly higher than other treatments. This result is similar to the findings of Eun et al (2002) who reported that high concentration of heavy metal causes imbalance of mineral nutrients in growing plants. These imbalances may have caused reduction in growth of the pumpkin plant treated with $\mathrm{Cd}$. The decrease in the uptake of nutrients by shoot may be attributed to a decrease in nutrient content because of increase in $\mathrm{Cd}$ application. Reduction in nutrient content and internal ratios of nutrients may have occurred in the pumpkin under Cd stress as earlier reported by Pinero et al. (2002). Root mineral nutrients and uptakeby T. occidentalis: The mineral ion concentration and uptake in the root are shown in Tables 6 and 7 respectively. These minerals and their uptake also declined with increased $\mathrm{Cd}$ concentration. In the greenhouse and field trials, significant differences were detected among the various levels of $\mathrm{Cd}$ in the mineral content of the root. The uptake of these minerals by the root in the greenhouse and field trials also recorded significant differences among the various treatments. The alteration of mineral elements in the root by the $\mathrm{Cd}$ treatment may be attributed to $\mathrm{Cd}$ physically blocking mineral ions from the absorption site of roots leading to reduction in root growth as shown by

Table 4. Shoot mineral content as influenced by various levels of cadmium in the greenhouse and field trials $(\%)$.

\begin{tabular}{|c|c|c|c|c|c|c|c|c|c|c|}
\hline $\begin{array}{l}\text { Heavy } \\
\text { metal }\end{array}$ & $\begin{array}{l}\mathrm{mg} / 5 \mathrm{~kg} \\
\text { soil }\end{array}$ & $\mathrm{N}$ & $\mathrm{P}$ & K & $\mathrm{Mg}$ & $\mathrm{Ca}$ & $\mathrm{Na}$ & $\mathrm{Fe}$ & $\mathrm{Mn}$ & $\mathrm{Zn}$ \\
\hline \multirow{6}{*}{$\mathrm{Cd}$} & \multicolumn{10}{|c|}{ Greenhouse trial } \\
\hline & $\overline{0}$ & $3.04 a$ & $0.56 \mathrm{a}$ & $3.79 a$ & $0.92 \mathrm{a}$ & $2.69 a$ & $3.11 \mathrm{a}$ & $0.32 \mathrm{a}$ & $0.40 \mathrm{a}$ & $\overline{0.48 \mathrm{a}}$ \\
\hline & 50 & $2.90 \mathrm{~b}$ & $0.48 b$ & $2.81 \mathrm{~b}$ & $0.83 b$ & $1.07 \mathrm{~b}$ & $2.17 \mathrm{~b}$ & $0.25 b$ & $0.34 b$ & $0.32 b$ \\
\hline & 100 & $2.36 \mathrm{c}$ & $0.38 \mathrm{c}$ & $1.77 \mathrm{c}$ & $0.71 \mathrm{c}$ & $0.89 \mathrm{c}$ & $2.03 \mathrm{c}$ & $0.15 \mathrm{c}$ & $0.16 \mathrm{c}$ & $0.16 \mathrm{c}$ \\
\hline & 200 & $1.78 \mathrm{~d}$ & $0.28 \mathrm{~d}$ & $1.07 \mathrm{~d}$ & $0.61 \mathrm{~d}$ & $0.78 \mathrm{~d}$ & $0.81 \mathrm{~d}$ & $0.11 \mathrm{~d}$ & $0.11 \mathrm{~d}$ & $0.10 \mathrm{~d}$ \\
\hline & Rate kgha ${ }^{-1}$ & & & & & d trial & & & & \\
\hline \multirow[t]{4}{*}{$\mathrm{Cd}$} & 0 & $2.36 \mathrm{a}$ & $0.27 \mathrm{~s}$ & $3.57 \mathrm{a}$ & $0.84 a$ & $2.84 \mathrm{a}$ & $3.17 \mathrm{a}$ & $0.24 \mathrm{a}$ & $0.35 a$ & $0.43 \mathrm{a}$ \\
\hline & 20 & $2.13 b$ & $0.22 b$ & $2.69 b$ & $0.71 b$ & $0.96 b$ & $2.44 \mathrm{~b}$ & $0.18 b$ & $0.24 \mathrm{~b}$ & $0.24 b$ \\
\hline & 40 & $2.02 \mathrm{c}$ & $0.18 \mathrm{c}$ & $2.09 \mathrm{c}$ & $0.64 \mathrm{c}$ & $0.61 \mathrm{c}$ & $2.04 \mathrm{c}$ & $0.13 c$ & $0.19 \mathrm{c}$ & $0.13 c$ \\
\hline & 80 & $1.77 \mathrm{~d}$ & $0.15 \mathrm{~d}$ & $1.03 \mathrm{~d}$ & $0.48 \mathrm{~d}$ & $0.46 \mathrm{~d}$ & $1.23 \mathrm{~d}$ & $0.07 \mathrm{~d}$ & $0.13 \mathrm{~d}$ & $0.05 \mathrm{~d}$ \\
\hline
\end{tabular}

Mean values with the same letter in the column are not significantly different from one another at $5 \%$ level of probability. 
Table 5. Shoot mineral uptake as influenced by various levels of cadmium in the greenhouse and field trials $\left(\mathrm{mgkg}^{-1}\right)$.

\begin{tabular}{|c|c|c|c|c|c|c|c|c|c|c|}
\hline $\begin{array}{l}\text { Heavy } \\
\text { metal }\end{array}$ & $\begin{array}{l}\mathrm{mg} / 5 \mathrm{~kg} \\
\text { soil }\end{array}$ & $\mathrm{N}$ & $P$ & K & $\mathrm{Mg}$ & $\mathrm{Ca}$ & $\mathrm{Na}$ & $\mathrm{Fe}$ & $\mathrm{Mn}$ & $\mathrm{Zn}$ \\
\hline & \multicolumn{10}{|c|}{ Greenhouse trial } \\
\hline \multirow[t]{5}{*}{$\mathrm{Cd}$} & 0 & $136.51 \mathrm{a}$ & $25.31 \mathrm{a}$ & $170.22 \mathrm{a}$ & $41.13 \mathrm{a}$ & $135.62 \mathrm{a}$ & $139.45 a$ & $14.21 \mathrm{a}$ & $17.83 a$ & $21.70 \mathrm{a}$ \\
\hline & 50 & $103.37 b$ & $17.19 b$ & $99.89 b$ & $29.49 b$ & $38.17 b$ & $76.98 b$ & $8.80 \mathrm{~b}$ & $11.95 \mathrm{~b}$ & $11.43 b$ \\
\hline & 100 & $77.81 b$ & $12.66 \mathrm{~b}$ & $58.21 \mathrm{c}$ & $23.20 \mathrm{~b}$ & $29.19 b$ & $66.73 b$ & $5.01 \mathrm{c}$ & $5.36 \mathrm{c}$ & $5.11 \mathrm{c}$ \\
\hline & 200 & $43.05 b$ & $6.15 c$ & $25.37 \mathrm{~d}$ & $14.33 c$ & $18.88 \mathrm{c}$ & $19.04 \mathrm{c}$ & $2.79 \mathrm{c}$ & $2.66 \mathrm{c}$ & $2.48 \mathrm{c}$ \\
\hline & Rate $\mathrm{kgha}^{-1}$ & & & & Field tri & & & & & \\
\hline \multirow[t]{4}{*}{$\mathrm{Cd}$} & 0 & $195.00 \mathrm{a}$ & $22.30 \mathrm{a}$ & $296.10 \mathrm{a}$ & $69.62 \mathrm{a}$ & $235.71 \mathrm{a}$ & $256.50 a$ & $19.74 a$ & $28.59 a$ & $35.46 a$ \\
\hline & 20 & $123.90 b$ & $12.88 b$ & $164.00 \mathrm{~b}$ & $42.22 \mathrm{~b}$ & $56.06 \mathrm{~b}$ & $142.70 \mathrm{~b}$ & $11.61 \mathrm{~b}$ & $14.17 \mathrm{~b}$ & $14.78 b$ \\
\hline & 40 & $100.10 \mathrm{c}$ & $9.62 c$ & $109.00 \mathrm{c}$ & $32.36 \mathrm{c}$ & $31.56 \mathrm{~b}$ & $101.50 \mathrm{c}$ & $6.72 \mathrm{c}$ & $10.18 \mathrm{c}$ & $6.82 \mathrm{c}$ \\
\hline & 80 & $63.80 \mathrm{~d}$ & $6.24 \mathrm{~d}$ & $77.60 d$ & $17.89 \mathrm{~d}$ & $18.20 b$ & $44.20 \mathrm{~d}$ & $2.75 \mathrm{~d}$ & $5.04 \mathrm{~d}$ & $2.07 \mathrm{~d}$ \\
\hline
\end{tabular}

Mean values with the same letter in the column are not significantly different from one another at $5 \%$ level of probability.

the root weight. The decrease on the root weight may also be related to the decrease in Ca root tips of the pumpkin leading to decrease in cell division or cell elongation (Rout and Das, 2003). Moreover, the Cd concentration may have damaged the tissue cells of vascular bundles, which resulted in the inhibition of conduction of water molecules and other nutrients from root to aerial parts of the plant hence there was a reduction in the plant nutrients. This reduction in plant nutrients is similar to finding of Eun et al. (2002) and Azmat et al. (2006).

Cadmium content (\%) and uptake $\left(\mathrm{mgkg}^{-1}\right)$ by $\mathrm{T}$. occidentalis: The $\mathrm{Cd}$ component of the crop is shown in Table 8. The Cd content of the shoot and root increased with increase in $\mathrm{Cd}$ application. In the greenhouse trial, the $200 \mathrm{mg}$ Cd treatment was significantly higher in the accumulation of Cd by shoot and the root. The $200 \mathrm{mg}$ $\mathrm{Cd}$ treatment in the field also recorded high $\mathrm{Cd}$ concentration in the root while there were no significant differences among the treatment in $\mathrm{Cd}$ content of the shoot. In the greenhouse trial, the $200 \mathrm{mg} \mathrm{Cd}$ significantly had a higher value in $\mathrm{Cd}$ uptake by the shoot whereas the $100 \mathrm{mg} \mathrm{Cd}$ and $200 \mathrm{mg} \mathrm{Cd}$ were significantly higher than other treatments in root uptake of Cd. The $40 \mathrm{kgha}^{-1}$ and $80 \mathrm{kgha}^{-1}$ treatments were significantly higher than other application in Cd uptake by shoot and the root in the field trial. The uptake of $\mathrm{Cd}$ also increased with increase in the $\mathrm{Cd}$ application. In this study, the root accumulated more $\mathrm{Cd}$ than the shoot making the plant a metal excluder. The metal excluder (Raskin et al., 1994) prevent metal from entering their aerial part or maintains low and constant metal concentration over a broad range of the concentration in soil and they mainly restrict metal in their root as shown by pumpkin in this study. A metal excluder restricts heavy metals to root by actively growing roots, which provide a barrier to the movement of heavy metal to above shoot. Jones et al. (1973), Malone et al. (1974), Begonia (2006) and Kumar et al. (1995) have earlier reported similar results with various broad leaf vegetables grown in various soils laden with heavy metals. Marcilene et al. (2003) also reported that $\mathrm{Cd}$ is generally present in higher rates in roots and moderate to great quantities in the aerial parts of plants.

The low concentration of $\mathrm{Cd}$ in the control plant at harvest is below the specified maximum acceptance level of 0.3 $\mathrm{mgkg}^{-1}$ for leafy vegetables by WHO (1984) and the Codex Alimentarius Commission (2004). The low level of this $\mathrm{Cd}$ in the control treatment makes the plant to be less

Table 6. Root mineral content as influenced by various levels of cadmium in the greenhouse and field trials $(\%)$.

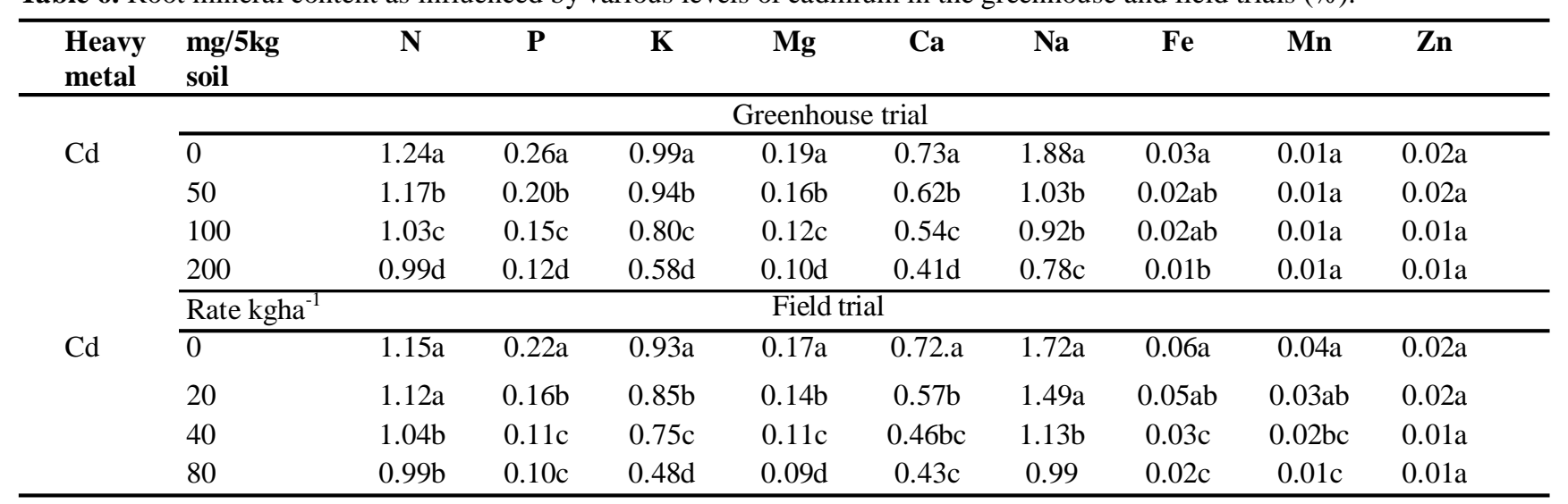

Mean values with the same letter in the column are not significantly different from one another at $5 \%$ level of probability 
Table 7. Root mineral uptake as influenced by various levels of cadmium in the greenhouse and field trials $\left(\mathrm{mgkg}^{-1}\right)$.

\begin{tabular}{llccccccccc}
\hline $\begin{array}{l}\text { Heavy } \\
\text { metal }\end{array}$ & $\begin{array}{l}\mathrm{mg} / 5 \mathrm{~kg} \\
\text { soil }\end{array}$ & $\mathrm{N}$ & $\mathrm{P}$ & $\mathrm{K}$ & $\mathrm{Mg}$ & $\mathrm{Ca}$ & $\mathrm{Na}$ & $\mathrm{Fe}$ & $\mathrm{Mn}$ & $\mathrm{Zn}$ \\
\hline & & & & \multicolumn{7}{c}{ Greenhouse trial } \\
\hline $\mathrm{Cd}$ & 0 & $10.69 \mathrm{a}$ & $2.23 \mathrm{a}$ & $8.54 \mathrm{a}$ & $1.63 \mathrm{a}$ & $6.33 \mathrm{a}$ & $16.17 \mathrm{a}$ & $0.26 \mathrm{a}$ & $0.11 \mathrm{a}$ & $0.17 \mathrm{a}$ \\
& 50 & $8.80 \mathrm{~b}$ & $1.53 \mathrm{~b}$ & $7.06 \mathrm{~b}$ & $1.22 \mathrm{~b}$ & $4.67 \mathrm{~b}$ & $7.77 \mathrm{~b}$ & $0.13 \mathrm{~b}$ & $0.08 \mathrm{~b}$ & $0.15 \mathrm{a}$ \\
& 100 & $6.76 \mathrm{c}$ & $1.02 \mathrm{c}$ & $5.27 \mathrm{c}$ & $0.74 \mathrm{c}$ & $3.59 \mathrm{c}$ & $6.08 \mathrm{c}$ & $0.11 \mathrm{~b}$ & $0.03 \mathrm{c}$ & $0.07 \mathrm{~b}$ \\
& 200 & $5.75 \mathrm{~d}$ & $0.68 \mathrm{~d}$ & $3.39 \mathrm{~d}$ & $0.56 \mathrm{c}$ & $2.42 \mathrm{~d}$ & $4.59 \mathrm{~d}$ & $0.06 \mathrm{~b}$ & $0.03 \mathrm{c}$ & $0.06 \mathrm{~b}$ \\
\hline & Rate $\mathrm{kgha}^{-1}$ & & & & \multicolumn{7}{c}{ Field trial } & & & \\
\hline $\mathrm{Cd}$ & 0 & $17.99 \mathrm{a}$ & $3.39 \mathrm{a}$ & $14.47 \mathrm{a}$ & $2.65 \mathrm{a}$ & $11.22 \mathrm{a}$ & $26.94 \mathrm{a}$ & $0.93 \mathrm{a}$ & $0.67 \mathrm{a}$ & $0.37 \mathrm{a}$ \\
& 20 & $15.05 \mathrm{~b}$ & $2.14 \mathrm{~b}$ & $11.46 \mathrm{~b}$ & $1.92 \mathrm{~b}$ & $7.70 \mathrm{~b}$ & $21.83 \mathrm{~b}$ & $0.62 \mathrm{~b}$ & $0.40 \mathrm{~b}$ & $0.28 \mathrm{ab}$ \\
& 40 & $9.47 \mathrm{c}$ & $1.07 \mathrm{c}$ & $7.11 \mathrm{c}$ & $1.04 \mathrm{c}$ & $4.35 \mathrm{c}$ & $10.63 \mathrm{c}$ & $0.30 \mathrm{c}$ & $0.16 \mathrm{c}$ & $0.10 \mathrm{~b}$ \\
& 80 & $9.05 \mathrm{c}$ & $0.83 \mathrm{c}$ & $4.43 \mathrm{~d}$ & $0.79 \mathrm{c}$ & $3.30 \mathrm{~d}$ & $9.13 \mathrm{c}$ & $0.18 \mathrm{c}$ & $0.06 \mathrm{c}$ & $0.09 \mathrm{~b}$ \\
\hline
\end{tabular}

Mean values with the same letter in the column are not significantly different from one another at $5 \%$ level of probability.

Table 8. Cadmium content (\%) and uptake $\left(\mathrm{mgkg}^{-1}\right)$ by T. occidentalis in the greenhouse and field trials.

\begin{tabular}{|c|c|c|c|c|c|}
\hline $\begin{array}{l}\text { Heavy } \\
\text { metal }\end{array}$ & $\begin{array}{l}\mathrm{mg} / 5 \mathrm{~kg} \\
\text { Soil }\end{array}$ & $\begin{array}{c}\text { Shoot Cd } \\
\text { content }\end{array}$ & $\begin{array}{l}\text { Root Cd } \\
\text { content }\end{array}$ & $\begin{array}{c}\text { Shoot Cd } \\
\text { uptake }\end{array}$ & $\begin{array}{c}\text { Root Cd } \\
\text { uptake }\end{array}$ \\
\hline & \multicolumn{5}{|c|}{ Greenhouse trial } \\
\hline \multirow[t]{5}{*}{$\mathrm{Cd}$} & 0 & $0.0001 \mathrm{c}$ & $0.02 \mathrm{~d}$ & $0.004 \mathrm{~d}$ & $0.14 \mathrm{c}$ \\
\hline & 50 & $0.04 \mathrm{bc}$ & $0.58 \mathrm{c}$ & $1.39 \mathrm{c}$ & $4.31 \mathrm{~b}$ \\
\hline & 100 & $0.06 b$ & $1.14 \mathrm{~b}$ & $1.97 \mathrm{~b}$ & $7.50 \mathrm{a}$ \\
\hline & 200 & $0.13 \mathrm{a}$ & $1.34 \mathrm{a}$ & $2.61 \mathrm{a}$ & 7.71a \\
\hline & Rate kgha $^{-1}$ & \multicolumn{4}{|c|}{ Field trial } \\
\hline \multirow[t]{4}{*}{$\mathrm{Cd}$} & $\overline{0}$ & $0.0001 \mathrm{a}$ & $0.02 \mathrm{~d}$ & $0.008 \mathrm{c}$ & $0.31 \mathrm{c}$ \\
\hline & 20 & $0.03 \mathrm{a}$ & $0.45 c$ & $1.05 \mathrm{~b}$ & $6.02 \mathrm{~b}$ \\
\hline & 40 & $0.04 \mathrm{a}$ & $0.73 b$ & $1.28 \mathrm{ab}$ & $6.74 \mathrm{ab}$ \\
\hline & 80 & $0.05 \mathrm{a}$ & $0.81 \mathrm{a}$ & $2.23 \mathrm{a}$ & $7.43 \mathrm{a}$ \\
\hline
\end{tabular}

Mean values with the same letter in the column are not significantly different from one another at $5 \%$ level of probability.

hazardous to man when consumed. Those treated with the $\mathrm{Cd}$ deviated from this acceptable level making it hazardous to health when regularly consumed.

\section{Conclusion}

In conclusion, the application of $\mathrm{Cd}$ had a negative influence on the growth parameters and dry matter yield of the plant. The nutrient content and uptake by the plant at various levels of treatment decreased with increased concentration of the $\mathrm{Cd}$ whereas the root of the treated pumpkin accumulated higher $\mathrm{Cd}$ ions than the shoot. However, the shoot of the control plants had low $\mathrm{Cd}$ component when compared to the treated plants. The soil nutrients content and the oxides also decreased at various levels of $\mathrm{Cd}$ treatment whereas the $\mathrm{Cd}$ component of the soil increased with increased $\mathrm{Cd}$ application. From the aforementioned results, it is advisable not to plant pumpkin in soils suspected to be laden or high in cadmium materials.

\section{REFERENCES}

Adriano, D.C (1986). Trace elements in the terrestrial environment, New York: Spinger Verlag.

ATSDR (1999). Toxicological profile for cadmium. U.S Department of Health Services. Agency for Toxic Substances and Disease Registry (ATSDA ), 205-93-0606
AOAC (1970). Official methods of analysis, Association of Official Analytical Chemists (AOAC) Ed 11 Washington D. C.

Azmat, R and Haider, S (2007). Pb Stress on phytochemistry of seedlings Phaseolus mungo and Lens culinaris. Asian J ournal of Plant Science, 6(2): 332-337

Azmat, R. Haider, S and Askari, S. (2006). Phytoxicity of $\mathrm{Pb}$ $\mathrm{I}$ : Effects of $\mathrm{Pb}$ on germination, growth, morphology and histomorphology of Phaseolus mungo and Lens Culinaris. Pakistan J ournal of Biological Science, 9:979-984

Azmat, R., Iftikar, B., Khanum, T; Hayyat, A., Talat, R. and Uddin, F. (2005). The inhibition of bean plant metabolism by cadmium metal 11: The inhibition of mineral acquisition in heavy metal contaminated environments. Pakistan J ournal of Biological Sciences, 8:748-750

Begonia, G.B. (2006). Comparative lead uptake and responses of plants grown in lead contaminated soils. www.ejoun3.htm.

Black, C.A,(1965). Methods of soil analysis. Agronomy No 9 Part 2. America Society of Agronomy. Madison, Wisconsin. Brown, K.W; Thomas, J.C. and Slowey, J.F. (1983). Metal accumulation by bermidagrass grown on four diverse soils amended with secondarily treated sewage effluent. Water, Air and Soil pollution, 20(4): 431-446.

Codex Alimentarius Commission (2004). Report of the $36^{\text {th }}$ Session of Codex Alimentarius Committee on Food Additives and Contaminants Rotterdam, The Netherlands 22-26 March. 
Day, P. R. (1965). Particle fractionation and particle size analysis: In methods of soil analysis, (C.A. Black Ed).Agronomy No 9 Part 1. American Society of Agronomy Madison, Wisconsin

Eun, S.O., Youn, H.S. and Lee, Y. (2002). Lead disturbs microtubile organization in root meristem of Zea mays Physiology of Plants, 110:357-365.

Foy, C.D., Chaney, R.L and White, M.C. (1978). The physiology of metal toxicity in plants. Annual Review of Plant Physiology, 29:511-566.

Godzik, B. (1993). Heavy metal contents in plants from zinc dumps and reference area. Poland Botanical Studies, 5:113132.

International Institute of Tropical Agriculture (IITA) (1979). Selected methods for soil and plant analysis. Manual Series No 1. pp 70

Jackson, M.L.(1962). Soil chemical analysis. Prentice Hall, New York. 263-268

John, M. K., Vanlaerhoven, C. J. and Chukwuma, C. (1972). Plant uptake and phytotoxicity of cadmium added to soils. Environmental Science and Technology, 6 (2), 1005-1009.

Jones, L.H.P., Clement, C. R. and Hoope, M. J. (1973). Lead uptake from solution by perennial ryegrass and its transport from root and shoots. Plant Soil, 38:403-414.

Kachenko, A. and Singh, B. (2004). Heavy metals contamination of home grown vegetables near metal smelter in NSW. Super Soil: 2004 Australian/New Zealand Soil Conference, 5-9 December, 2004, Adelaide.

Khan, D. H. and Frankland, R. (1983). Effects of cadmium and lead on raddish with particular reference to movement of metals through soil profile and plant. Plant and Soil, 70: 335-345.

Kramer, F. and Konig, W. (1983). Cadmium contents in soil and plants: the growth and nutrient concentration of tomato and egg plant. Plant and soil, 74 (3):387-354.

Kumar, P.B.A.N., Dushenkov, V., Matto, H. and Raskin, I. (1995). Phytoextraction: The use of plants to remove heavy metals from soils. Environmental Science and Technology, 29:1232-1238.

McBride, M. B. (2003). Toxic metals in sewage sludge amended soil: Has promotion of beneficial use discounted the risk? Advance Environmental Research, 8: 5-17

Malone, C.D. Koeppe, D.E. and Miller, R.I. (1974). Localization of lead accumulated by corn plants. Plant Physiology, 53:385-394.

Marcilene, F. B., Marines, A. J., Margarate, S. S. and Ervin, L. (2003). Lead behaviors in soil treated with contaminated sewage sludge and cultivated with maize. B razillian Archives of Biology and Technology, 46 (4): 1-11.

Murphy, J. and Riley, J. P. (1962). Analytical chemistry. Acta, 27:31-36.

Nasu, Y., Kugimoto, M., Tanaka, O., Yanase, D., and Takimoto
A. (1984). Effect of cadmium, copper and cobalt existing in the medium on the growth and flowering of Lemna pancicostata in relation to their absorption. Enviromental Pollution. 33(3):262-274.

Orhue, E. R. (2008). Phytoavailability of lead and chromium to pumpkin in an ultisol $\mathrm{Ph}$. D Thesis University of Benin, Benin City, Nigeria.

Payne, R.W. (2002). Gent stat 6.1: Reevence manual VSN International Ltd. Oxford.

Pinero, H.J.L., Miti, R.K., Julia-Verdestar, M.A., Diaz, G.G., Dnzalez, A.N., Cardenas-Avila, M.L. and Orough- Bakhih, R. (2002). Effect of $\mathrm{Pb}$ and $\mathrm{Cd}$ on seedlings, growth, chlorophyll and protein contest of common bean. Phascolus vulgaris, Alfalfa (Medigago sativa), Avena (Avena santiva and rye grass (Lolum multiflorum) selected as hyper accumulator of heavy metal. Research on Crops, 3:473480.

Raskin, I., Kumar, P.B.A., Dushenkovs, N. and Salt, D. (1994). Bio-concentration of heavy metals by plants. Current Opinion on Biotechnology, 5: 285-290.

Rauser, W.E. (1990). Phytochelatins. Annual Review of Biochemistry, 59: 61-86..

Re, M., Gavagola, M.G., Crovato, E. and Cella, R. (1983). Cadmium distribution within corn plants as a function of Cadmium loading of the soil. Environmental Research, 30 (1) 44-49.

Rout, G. R. and Das, P. (2003). Effect of metal toxicity on plant growth and metabolism 1 Zinc. Agronomie, 23: 3-11

Schwertmann, U. (1991). Solubility and dissolution of iron oxides. Plant and Soil, 130:1-25.

Singh, B. (2001). Heavy metals in soils: sources, chemical reactions and forms In: Geo-environment proceeding of $2^{\text {nd }}$ Australia and New Zealand conference of environmental geotechnic 2001 New South Wales.

Soon, Y. K. and Abboud, S. (1993). Cadmium, chromium, lead and nickel In: Soil sampling and methods of soil analysis (eds M.R. Carter). Canadian Society of Soil Science, 101108.

Stiffens, J.C. (1990). The heavy metal binding peptides of plants. Annual Review of Plant Physiology and M olecular Biology, 41:553-575.

Subramani, A., Saravanan, S., Taraizhuiyay, P. and Lakshmanalharg, A.S. (1997). Influences of heavy metals non germination and early seedlings growth of Vigna mungo L. Pollution Research, 16(1): 29-31.

Tam, Y.L. and Singh, B. (2004). Heavy metals availability at industrially contaminated soils in NSW, Austral: In A.L. Juhaz, G. Magesan and R. Naidu (eds). Waste Management, Science. Publishers Plymouth $97-120$.

WHO (World Health Organization) (1984). Guidelines for soil, water and plant quality. Vol. 1 Recommendation W.H.O. Geneva 130p. 